\title{
THE CONTRIBUTION OF AN INTERACTIVE MULTIMEDIA IN TEACHING SIMPLE PRESENT TENSE FOR JUNIOR HIGH STUDENT
}

\author{
DJOKO SRI BIMO \\ UT Surakarta \\ djokosb@ecampus.ut.ac.id \\ SRI MURNI \\ UT Surakarta \\ srimurni@ecampus.ut.ac.id \\ MARIA YUSTINA RENSI DARTANI \\ UPGRIS Semarang \\ mariayustina68@gmail,com
}

DOI : http://dx.doi.org/10.29300/ling.v6i2.3646

\begin{abstract}
Learning English in Junior High School emphasizes on four language skills, they are speaking,writing, reading,and listening. However, it sometimes collides with the complexity of grammar, one of which is learning the present simple present tense in which for some people is acomplicated matter and makes it difficult for them in understanding English. Departing from this problem, a new breakthrough is needed, so that students are interested in learning English. Today's education emphasizes on how to learn by utilizing technological sophistication, then Multimedia is one of the technologies that can be used to stimulate thoughts, feelings, concerns, and abilities or skills of learners. This technology has a very positive impact on students since it can provide solutions and ease in carrying out the learning process. The purpose of the study was to describe the implementation of interactive multimedia and to describe the level of defiance of the eighth grade students of SMP Muhammadiyah I Surakarta in learning of Simple Present Tense. The study employed a quantitative research approach, and the type used was an experiment. The experimental design in this study was randomized pre-test post-test design. The sample in this study was class VIII A, assigned as the Experiment Group 1 (EG1) who was taught by using interactive multimedia, while class VIII B, assigned as the Experimental Group 2 (EG2) who was taught by using the lecturing method and supported by using a handout. After learning was complete, both groups were given the same post-test. The result found that the EG1 who given treatment by using interactive multimedia got higher results than the EG2 who treated by Handout, where the mean score of the EG1 was 83.04, while the mean score of the EG2 was 72.96. Based on the result above, it was indicated that the students of SMP Muhammadiyah I Surakarta was more comprehend in learning The Simple Present Tense by using interactive multimedia better than conventionally, since interactive multimeda can build their creativity power and increase their understanding in English.
\end{abstract}

Keywords: Interactive multimedia, simple present tense, learning outcomes

\section{INTRODUCTION}

Learning English at Junior High School, all the learning activities are centered on students and still integrate with four language skills, those are listening, reading, writing, and

How to cite this article: Bimo, D., Murni, S., \& Dartani, M. (2020). The contribution of an interactive multimedia in teaching simple present tense for junior high students. Linguists : Journal Of Linguistics and Language Teaching, 6(2), 14-22. doi: http://dx.doi.org/10.29300/ling.v6i2.3646 
speaking. The importance of instructional media in the teaching learning process was stated by several education experts. Hamalik (2008) stated that learning media helped more students in the teaching learning in the classroom. In line with the above statements, Situmorang (2009) stated that learning media can create an effective learning situation, and provide learning motivation to students. Thus, the use of media as a learning resource in learning activities has a very important meaning. In addition to complementing, maintaining and enriching the learning process, it has the position to improve the academic activities of students.

In this era of globalization, educators are required to master information and communication technology to support the learning process as well as a form of sustainable professional development. As one form of implementation of these demands is by developing ICT-based learning presentation media. The use of multimedia-based learning media that presents visualization of subject matter will greatly help not only educators in delivering material but also students as learning subjects, so that learning objectives can be achieved.

It cannot be denied that multimedia technology is able to make a big impression in the field of communication and education because it can integrate text, graphics, animation, audio and video. This integration is a unit that can display information, messages or lesson content and is able to process information and provide feedback in the form of new information to users (Waryanto: 2013).

Interactive multimedia is one of the innovations that can be used in fulfilment of the needs for supplement teaching materials. Interactive multimedia-based learning is a learning by using multimedia devices as its main means. Interactive multimedia technology fully combined by computer technology, video and audio system to get a better combination and to increase the interaction between the user and the computer. Audio and visual offerings in the multimedia learning make visualization more interesting. The multimedia display will make students more free to choose, to synthesize and to elaborate the knowledge they want to understand. Furthermore, the use of interactive multimedia teaching materials can increase new desires and interests, generate motivation and stmulate learning activities and even have a psychological effect on students.

\section{Multimedia}

According to Sutedjo (2002:51), multimedia is a variety of media that are combined into one work unit to produce information that has a very high interactive communication value. Turban (2002) suggested that multimedia is a combination of at least two input or output media. This media can be in the form of audio ( music sound), animation, video , text, graphics and images. 
Vaughan (2011) in his book entitled "Multimedia, making it Work" described multimedia and the elements contained there. According to Vaughan, these elements are: 1) text, that is the simplest medium in conveying information. Text is a vital element in most multimedia applications such as the menus, navigation system and even the programming itself. 2) Graphics, that is two dimensional as well as three dimensional representations as an illustration medium that clarifies information delivery. 3) Animation, that is the display of images quickly to get the impression of movement. Animation itself means aseries of images that move alternately at a very fast time as if moving. Animations are often referred to as live pictures. 4) Sounds and music, that can be used in making multimedia, namely soundwaveforms, MIDI music, audio CD music and MP3 5) image, that is a spatial representation of an object. Images can be divided into images from the real world ( the result of scanned photo), images in cyberspace (made with programs) and combined images between the real world and the virtual world. 6) video, provide a rich source of multimedia applications. Video have similarities to animation, except that they are captured from real world scenes.

\section{Interactive Multimedia}

Suyanto (2012) stated that multimedia as a presentation medium is different from multimedia as a learning medium. Presentation media does not require users to interact actively in it, even though there ia a vague interactivity. Interactive learning media involved users in activities that are mentally demanding in learning. From this perspectives, the specific mental assets required in instructional media can be generated through systematic manipulation of instructional events.

Blackwell (1977:1) in "Multimedia Application in Education" stated that interactive multimedia is a combination of various media with links or tools that allow teachers or students to control, to interact and to communicate with computers. When the user can control what and whenever the elements are in the media, this process is called interactive multimedia. So, by using multimedia, students can not only see and hear but also can stimulate the commands in it. Basically, one of the objectives of learning with interactive multimedia is to replace and ,or complement and support the elements, they are: objectives, materials, methods, and learning process in conventional education system that are commonly used.

\section{Preliminary Study}

The implementation of English learning is carried out in two kinds of cycles, they are the oral cycles (listening and speaking) and the writing cycle (reading and writing). The teaching and learning process, however will get monotonous and tedious if the teacher who 
teaches the subject is lacks creativity and does not mastering English teaching methods, because teaching English is not just about writing vocabulary on the blackboard then students copy it on a note, after that students imitate the educator by saying the words or vocabulary that has been written. It was considered that those such learning model as a conventional one and it makes both students and educatorswill quickly.

The result of observations conducted by the researchers team showed that $85 \%$ of educators need an interactive learning media in the teaching learning process, in order to get the learning process runs more effectively. All this time they are still use the conventional methods and simple media, that's why students tend to be passive during learning. From the questionnaire distributed to 25 students who were taken as samples, $100 \%$ of students said that they needed an interactive learning media that they could use as a learning tool individually since they are generally reluctant to raise questions or opinions when learning takes place. The low learning motivation of students in learning English suspected to be cause of the low learning outcomes of English.

Based on the description above, educators need to provide an innovative, an effective and an interactive learning media for students, especially for learning Simple Present Tense. And to find out the contribution of interactive multimedia - based learning for the eighth grade of SMP Muhammadiyah 1 Surakarta, this study was conducted. The implementation of interactive multimedia in the Simple Present Tense is expected to give some contributions to educators.

\section{The Simple Present Tense}

In studying the simple present tense, many students have problems in it. They usually have some problems in finding out the verb form of simple present tense. It is caused by the pattern for the simple present tense have a certain role, in which it is formed by using the simple form of the verb that is called infinitive. The changing of the shape of verb for a single third person is also considered to be the cause of their confusion. The students still confuse about in adding $s$ or es ending in a verb.

\section{METHOD}

The research method used in the study was experimental method, The first experimental group was assigned by EG1 who is given treatment by using an interactive multimedia, while the second experimental group was assigned by EG2, who is given treatment by using the Lecturing method and Handout. The learning process is carried ot as many as $10 \mathrm{x}$ meetings, with a learning time 60 minutes in each. $(8 \mathrm{x}$ treatment +2 pre-test and post-test). The randomized pretest and posttest comparison groups are presented in Table 1 .

Linguists: Journal of Linguistics and Language Teaching

Vol. 6, No. 2, December 2020 
Table 1. Randomized pretest-posttest comparison group design

\begin{tabular}{|c|c|l|c|}
\hline Group & Pre-test & Treatment & Pos-test \\
\hline EG1 & $\mathrm{R}_{1}$ & Interactive Multimedia & $\mathrm{R}_{3}$ \\
\hline EG2 & $\mathrm{R}_{2}$ & Lecturing method and Handout & $\mathrm{R}_{4}$ \\
\hline
\end{tabular}

\section{Respondents}

The participants for the study were students of the eighth grades of SMP Muhammadiyah 1 Surakarta, which is located at Jalan Flores No 1 Kp Baru Pasar Kliwon, Surakarta, Central Java. There were 50 participants who take a part in the study, those were 25 students of class VIII A, and 25 students of class VIII B

\section{Instruments}

To support this study, some test were given. The interactive multimedia applied in this study was the use of white board with using the application of Microsoft Power Point. The supporting material like a handout included, it was included a description and explanation of the material being taught.

\section{Procedures}

The participants for the study were students of the eighth grades of SMP Muhammadiyah 1 Surakarta. There were 50 participants who take a part in the study, those were 25 students of class VIII A, and 25 students of class VIII B. Participants were divided into two treatment groups. Class VIII A signed as the EG1 and class VIII B signed as the EG2. The EG1 was taught by using interactive multimedia and the EG2 was taught by lecturing method and supported with the handout for the same materials of simple present tense. The data was carried out through test.

Pre-test was given before the experiment, and post-test was held immediately after the experiment was over. The Null hypothesis of no significant differences were constructed and tested, and then one-tailed t-test was used to compare the score of both groups and to analyze the hypothesis.The alpha level was set at .05 for the statistical tests.

Since the teaching learning process at this time did not allow to do face to face learning, so it was done online. The material of simple present tense has previously been distributed to each participants The treatment was carried out based on the schedule, and through google classroom the material discussed. The students'assignments were collected via the WhatsApp application, and via teachers'email, then the teacher sent them back to the team to be corrected and analyzed. 


\section{Data Analysis}

- Before carrying out the learning, first a pre-test is carried out, and getting the results for pre-test scores of both groups, then the data were processed. Differences in data collected from the EG1 pre-test and EG2 pre-test are presented in Table 2.

Table 2. Data on differences in Pre-Test experimental group 1 and experimental group 2

\begin{tabular}{|c|c|c|}
\hline Source of Variation & Experimental Group 1 & Experimental Group 2 \\
\hline Sum & 1360 & 1416 \\
\hline $\mathrm{n}$ & 25 & 25 \\
\hline Mean $(\mathrm{x})$ & 54.40 & 56.64 \\
\hline Variance $\left(\mathrm{s}^{2}\right)$ & 66.6667 & 140.9067 \\
\hline Standard Deviation $(\mathrm{s})$ & 8.16 & 11.87 \\
\hline
\end{tabular}

Data shows that the mean of EG1 is almost the same as the EG2 scores. The difference is not significant, and the group are homogenized. The difference in the test result of EG1 and EG2 shows that $\mathrm{t}$ count $=-0.78, \mathrm{t}$ table $=1.68$, and $\alpha=0,05$ which is presented in Figure 1 below:

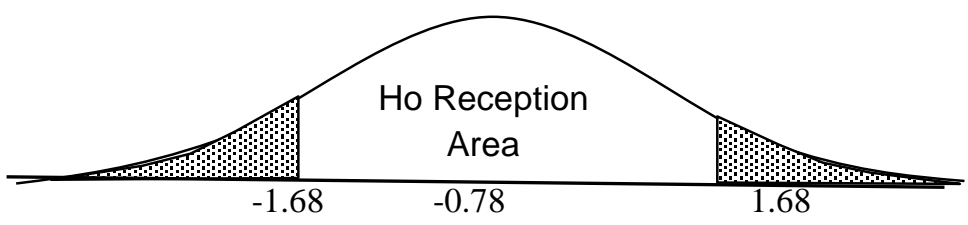

Figure 1. Data on differences in the two pre-test average of the experimental group 1 and group 2

Data shows that $\mathrm{t}$ count $=-0.78$ is between the Ho area. The differences between EG1 and EG2 was not significant in this experiment.

After finishing the whole experiment for eight weeks, and getting the results for posttest scores of both groups, then the data were processed. Data results differences in post-test EG1 and EG2 are shown in 3.

Table 3. Data on differences in Post-Test experimental group 1 and experimental group 2

\begin{tabular}{|c|c|c|}
\hline Source of Variation & Experimental Group 1 & Experimental Group 2 \\
\hline Sum & 2076 & 1824 \\
\hline $\mathrm{n}$ & 25 & 25 \\
\hline Mean $(\mathrm{x})$ & 83.04 & 72.96 \\
\hline Variance $\left(\mathrm{s}^{2}\right)$ & 65.7067 & 109.7067 \\
\hline Standard Deviation $(\mathrm{s})$ & 8.11 & 10.47 \\
\hline
\end{tabular}


The EG1 is higher than EG2. Therefore, learning through interactive multimedia is better than using Lecturing method and handout. The difference test results of two post-test meaning of the EG1 and EG2 stated that $\mathrm{t}$ count $>\mathrm{t}$ table $=1.68, \alpha=0,05$ which is presented in Figure 2 below:

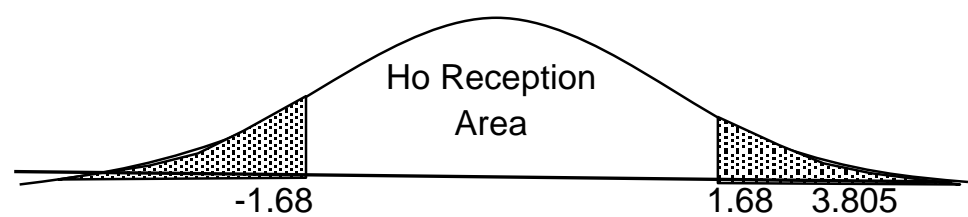

Figure 2. Data on differences in the two post-test average of the EG1 and EG2

This shows that EG1 with interactive multimedia is better than EG2 with the use of Lecturing method and handout. Why, is it like that? How can be like that? The simple reason was that by using in interactive media it made the students understand, comprehend better for the material, besides they were more active and can apply it in daily real life. Other reasons are the students can be focused, enthusiastic, and have an interest in learning. Moreover, students are able to express their ideas and can be more content with the objects displayed in the learning multimedia.

The previous study did by Wenas and Marasut (2017) in "Penggunaan Multimedia Interaktive video berbasis Komputer pada materi sistem persamaan linear dua variabel" showed that there was a positive effect in the use of an interactive multimedia toward the improvement of learning outcomes. This was shown by the average test result given to both classes, in which for the experimental class in initial test score was 15.517 and the final test score score was 82.41 , while the control class in initial test score was 12.586 , and the final test score was 70.35. Those all proved that an interactive multimedia give a good impact in the teaching process.

\section{FINDINGS AND DISCUSSIONS}

From the data on the table 3, it can be seen that the standard deviation of the EG1 was higher than the EG2, therefore it was conclude that interactive multimedia can give the contribution to the students' understanding to the simple present tense material.

Since the students of multimedia group performed better than the other experimental group, then the instrument was recommended. The use of multimedia appropriately in the teaching learning process and then it was accompanied by an interesting material considered will increase students' understanding of English and those all can motivated them in learning. Today, interactive multimedia is available and the teacher can teach a variety of 
subjects by using it, and it is regarded as the most powerful of all. But the teacher must be wise in determining and applying multimedia as a learning media in order to get maximum results in their achievement.

Based on the evaluation above, it can be concluded that the interactive multimedia for English subject was appropriate to be implemented in the teaching learning process for the eighth grade students in SMP Muhammadiyah 1 Surakarta. The strenth of this media is that students can be more active through the use of games, videos, material, and also interactive problems. The format arrangement of interactive multimedia learning included determining the software, basic layout, background, color choices, font types, animation, music, pictures, and videos for the application.The software used in operating this interactive multimedia is videoscribe sparkol.

\section{CONCLUSION}

Based on the findings, it can be concluded that there is any significance difference between the student's understanding of the simple present tense when were taught by using the interactive multimedia based learning media rather bettter than taught by lecturing method and usage of handout. It means that the use of interactive multimedia in teaching English indeed give great impacts to the students' understanding of simple present tense. The EG1 showed an improvement in performance and this improvement was statistically significant since the students got better achievement in their simple present tense understanding by using interactive multimedia. Then, through thisstudy, it is expected that the teachers are always create and do learning innovations by means of learning that is suitable with the student's condition and ability,so that they will be more motivated and have more interest in the learning process.

\section{REFERENCES}

Blackwell, John. (1997). Multimedia Application in Education. Retrieved on July 21 ${ }^{\text {st }}, 2020$ from http://web.viu.ca/.seeds/mm/index.html.

Hamalik Oemar. (2008). Perencanaan Pengajaran Berdasarkan Pendekatan Sistim. Jakarta: Bumi Aksara.

Situmorang, Robinson. (2009). Media Pembelajaran Berbasis Lingkungan: Makalah Pendidikan Dalam Pembelajaran. UNIMED- PSBTK.

Sutedjo Dharma Oetomo Budi. (2002). Perancangan Dan Pembangunan Sistem Informasi. Yogyakarta:Andi.

Suyanto Bambang Eka. (2012). Jurnal: Pembuatan Media Pembelajaran Corel Draw. Indonesia, ISSN, Journal on Computer Science-Speed Vol.8, No.2.

Turban, et all. (2002). Aplikasi Multimedia Interaktif. Yogyakarta: Paradigma.

Vaughan, T. (2011). Multimedia Making It Work ${ }^{\text {th }}$ Edition. New York: Mc Graw Hill. 
Wenas. R. Jhon Tatu Margareta and Marasut Alri. (2017). Penggunaan Multimedia interaktif video berbasis Komputer pada Materi Sistem Persamaan Linear Dua Variabel. Jurnal: Sains, Matematika \& Edukasi (JSME) FMIPA UNIMA Versi Online ISSN 2337-6139 Vol 5 No 1.

Wuryanto Nur Hadi. (2013). CD Pembelajaran Interaktif Sebagai Media Pembelajaran Berbasis Multimedia. Prosiding Seminar Ilmiah Nasional Komputer dan Sistem Intelijen. Universitas Gunadarma:Depok. Retrieved on October 16 $6^{\text {th }}$ 2013 from http://staffnew.uny.ac.id/upload/132304807/penelitian/CD+Pembelaran+Interaktif+Sebagai+ $\underline{\text { Salah+Satu+Media+Pembelajaran.pdf }}$ 